\title{
Comparison of proliferating cell nuclear antigen (PCNA) staining and BrdUrd-labelling index under different proliferative conditions in vitro by flow cytometry
}

\author{
F. Lohr, F. Wenz, S. Haas and M. Flentje \\ Department of Clinical Radiology, University of Heidelberg, Heidelberg, Germany
}

(Received 20 June 1994; revision accepted 30 November 1994)

\begin{abstract}
PC10 is a monoclonal antibody against proliferating cell nuclear antigen (PCNA). The staining pattern in immunochemistry depends on fixation and detergent extraction treatment. The aim of this study was to validate the flow cytometric PCNA assay against Bromodeoxyuridine-labelling index (BrdUrd-LI) under different proliferative conditions in vitro. Expression of PCNA in methanol fixed cells with, and without, prior detergent extraction with EDTA/Triton was compared to BrdUrdlabelling index in NIH-3T3 fibroblasts and human Caski tumour cells in exponential phase and under confluent conditions. Serum stimulation and serum starvation conditions were studied. The results for BrdUrd-LI and PCNA-index after extraction showed good correlation for 3 T 3 fibroblasts and for Caski cells, with some differences for serum withdrawn Caski cells. There was no correlation between the number of cells that were positive for PCNA without extraction and BrdUrd-LI. Spheroid cells with $G_{1}$-DNA-content showed an almost synchronous recruitment and progression through the cell cycle after trypsination and replating. Tightly bound PCNA paralleled this synchronicity whereas total PCNA did not change significantly. The results demonstrate that immunochemical detection of non-extractable PCNA-index gives similar results as compared with BrdUrd-labelling index under different proliferative conditions in vitro for different monolayer cell lines, whereas without extraction PCNA does not correlate with BrdUrd-LI in these fast growing cell lines due to its long half-life. PCNA expression parallels the progression through the cell cycle in V79 spheroids, a primitive model of tumour growth.
\end{abstract}

Several markers (S phase fraction, $\mathrm{Ki}-67$, different proto-oncogenes) are presently being evaluated as tools for determining the proliferative capacity of tumours (Yu, Woods \& Levison 1992).

$\mathrm{S}$ phase fraction can be assessed by $\left[{ }^{3} \mathrm{H}\right]$-thymidine labelling or by DNA flow cytometry. However, DNA histograms are difficult to evaluate for tumours with cell populations of different ploidy. Dolbeare et al. (1983) published a non-radioactive method to determine S phase fraction using Bromodeoxyuridine (BrdUrd). Begg et al. (1985) described a method for calculation of

Correspondence: Dr F. Lohr, Department of Oncological Diagnostics and Therapy, German Cancer Research Center, Im Neuenheimer Feld 280, 69120 Heidelberg, Germany. 
potential doubling time $\left(\mathrm{T}_{\text {poi }}\right)$ from a single sample. In an ongoing phase III study, Begg et al. (1992) showed that the BrdUrd-assay might help to choose between conventional or accelerated hyperfractionated radiotherapy in head and neck tumours. Potential doubling time and $\mathrm{S}$ phase labelling index $(\mathrm{LI})$ provide strongly related information in this study. Though the BrdUrd-LI currently is the gold-standard for $S$ phase detection, a cell inherent $S$ phase marker would be desirable.

$\mathrm{Ki}-67$ is a monoclonal antibody that apparently determines growth fraction and is of good prognostic value in lymphoma and leukaemia. Its value in solid tumours has not finally been determined (Brown \& Gatter 1990). The cDNA-sequence of the gene that codes for the Ki-67 antigen has been completely sequenced and the definition of the antigen in molecular terms has recently been reviewed (Schlüter et al. 1993, Duchrow, Gerdes \& Schlüter 1994).

PCNA was initially described as a corresponding antigen to an autoantibody in sera of patients with Lupus Erythematosus (Miyachi, Fritzler \& Tan 1978) and is identical with the nuclear protein 'Cyclin' (Mathews et al. 1984). It is a non-histone protein with a molecular weight of $36 \mathrm{kD}$ which functions as an auxiliary protein of DNA-polymerase delta (Prelich et al. 1987). PCNA is expressed beginning in late $G_{1}$, with a two to three-fold increase in $S$ and a decrease at the $S / G_{2}$ transition and during $G_{2}+M$. Two intranuclear populations exist (Bravo \& McDonaldBravo 1984, Galand \& Degraef 1989, Humbert et al. 1992). A tightly bound nucleolar form is only detectable from late $G_{1}$ to $G_{2}+M$. A second diffuse nucleoplasmic form, which can be extracted by an EDTA/Triton-containing lysing buffer prior to fixation with methanol (Landberg \& Roos 1991), is detectable during the whole cell cycle and is probably PCNA that has left the replisomes, and is acting as a reserve pool. It is degraded with a half-life of $20 \mathrm{~h}$ (Bravo \& McDonald-Bravo 1987).

PCNA is involved in DNA-repair and behaves like synthesis-associated PCNA in methanol or paraformaldehyde-Triton treatment (Shivji, Kenny \& Wood 1992, Stivala et al. 1993, Toschi \& Bravo 1988, Vriz et al. 1992). After serum stimulation of quiescent cells, PCNA gene expression was detected by Northern blotting after $10 \mathrm{~h}$, with a maximum after $16-18 \mathrm{~h}$ (Bravo \& McDonald-Bravo 1984). PCNA is expressed after c-myc and c-fos following serum stimulation (Vriz et al. 1992) and is necessary for the $\mathrm{G}_{1} / \mathrm{S}$ transition that can be inhibited by antisense nucleotides (Jakulski et al. 1988). It seems to be one of the final events that lead to DNA replication (Bravo \& McDonald-Bravo 1984).

Results of immunohistochemical studies using PCNA on normal and tumour tissue have been conflicting. Depending on the method of fixation and the antibody that was applied, either the $S$ phase fraction or the proliferation fraction were detected (Sasaki, Kurose \& Ishida 1993). Thus, studying PCNA in vitro under different proliferative conditions may help to interpret in vivo data.

For exponentially growing cell lines in vitro, a good correlation between BrdUrd-LI and the tightly bound PCNA-index was shown (Landberg \& Roos 1991, Sasaki et al. 1993).

We report on flow-cytometric detection of proliferating cell nuclear antigen (PCNA) in comparison with BrdUrd as an $\mathrm{S}$ phase marker using different rodent and human monolayer cell lines under different proliferative conditions in vitro, with and without detergent extraction prior to methanol fixation. Additionally, expression of PCNA in partially synchronized V79 spheroids was studied.

\section{MATERIALS AND METHODS}

\section{Cell lines and endpoints}

Caski human cervix carcinoma cells and NIH-3T 3 mouse fibroblasts were grown as monolayer cuitures in $20 \mathrm{ml}$ culture flasks with RPMI 1640 medium, supplemented with $1 \% \mathrm{~L}$-glutamine and 
$10 \%$ fetal calf serum (FCS) at $37^{\circ} \mathrm{C}$ in an atmosphere of $5 \% \mathrm{CO}_{2}$. For serum starvation and stimulation experiments medium was first changed to RPMI 1640 containing $1 \% \mathrm{~L}$-glutamin and a residual concentration of $1 \%$ FCS to prevent cell-detaching for both exponentially growing cells and cells that were confluent for 6 days. Cells were then trypsinized (EDTA $0.2 \% ; 2 \times 3 \mathrm{~min}$ at $37^{\circ} \mathrm{C}$, Trypsin $0.2 \% ; 5$ min at $37^{\circ} \mathrm{C}$, followed by blocking with $10 \%$ FCS-containing medium) and replated using medium supplemented with $10 \%$ FCS. Cells were trypsinized and harvested as described above, $24 \mathrm{~h}$ after serum withdrawal as well as $0,4,6,11,15$ and $19 \mathrm{~h}$ after serum induction (exponentially growing $3 \mathrm{~T} 3$ cells were more closely monitored after serum withdrawal (e.g. see Figure 4a)). They were then fixed, stained and analyzed as described below. V79 cells were grown as spheroids in spinner bottles with DMEM (1\% L-glutamin, 10\% FCS). After reaching a median diameter of approximately $300 \mu \mathrm{m}$, spheroids were disaggregated (Trypsin $0.2 \%, 1 \mathrm{ml}$; EDTA $0.2 \%, 1 \mathrm{ml}, 10 \mathrm{~min}$ at $37^{\circ} \mathrm{C}$ ) and replated as single cells. Aliquots of these cells were harvested 0,2 (not shown), 4, 5, 6, 8, 10,12, 14 and $24 \mathrm{~h}$ after plating.

\section{BrdUrd-labelling}

Cells $\left(5 \times 10^{6}\right)$ were incubated with BrdUrd $(15 \mu \mathrm{mol} / \mathrm{l})$ for $45 \mathrm{~min}$. Immediately afterwards they were trypsinized. No BrdUrd labelling was performed on V79 spheroids.

\section{Fixation and extraction}

After trypsination cells were resuspended in $600 \mu \mathrm{l}$ PBS and the suspension was then divided into three equal portions. For BrdUrd-detection, cells were fixed in $3 \mathrm{ml} 70 \%$ ethanol at $4^{\circ} \mathrm{C}$ for $30 \mathrm{~min}$. For detection of total PCNA cells were fixed in $3 \mathrm{ml}$ of absolute methanol at $-20^{\circ} \mathrm{C}$ for $10 \mathrm{~min}$, then kept at $4^{\circ} \mathrm{C}$ for $30 \mathrm{~min}$. For detection of DNA-bound PCNA, soluble PCNA was extracted by incubating the cells in $500 \mu \mathrm{l}$ EDTA $0.2 \%$ containing Triton $\mathrm{X}-100(2.5 \mu \mathrm{l} / \mathrm{ml})$ and BSA $(5 \mu \mathrm{l} / \mathrm{ml})$ for $15 \mathrm{~min}$ on ice, according to a protocol published by Landberg \& Roos (1991). Then the samples were fixed with methanol as described above.

\section{Immunochemical staining}

\section{BrdUrd}

For BrdUrd detection a modification of the method originally described by Dolbeare et al. (1983) was used. DNA denaturation was performed with $2 \mathrm{~N} \mathrm{HCl}$ in a waterbath at $37^{\circ} \mathrm{C}$ for $30 \mathrm{~min}$. Between all following steps cells were washed in $3 \mathrm{ml} P B S$ and taken up in a $24 \mathrm{G}$ syringe several times.

The staining protocol is a standard two-step procedure. One millilitre of PBS containing BSA $(10 \mu \mathrm{l} / \mathrm{ml})$ and Triton $\mathrm{X}-100(50 \mu \mathrm{l} / \mathrm{ml})$ was used for further permeabilization and non-specific blocking for $15 \mathrm{~min}$ at room temperature. The primary antibody (anti BrdUrd, B44, Becton Dickinson, San Jose, CA, USA) and, after washing, the FITC conjugated goat-anti-mouse IgG (Becton Dickinson) as a secondary antibody were used, each at a dilution of $1: 10$ in $100 \mu \mathrm{l}$ PBS containing BSA $(2 \mu \mathrm{l} / \mathrm{ml})$ for $30 \mathrm{~min}$ at room temperature. DNA-staining was achieved with $1.4 \mathrm{ml}$ propidium iodide $(20 \mu \mathrm{g} / \mathrm{ml})$ together with RNAase $(30 \mu \mathrm{g} / \mathrm{ml})$ to remove double-strand RNA ( $15 \mathrm{~min}$ in the dark, room temperature). Samples were then stored at $4^{\circ} \mathrm{C}$ until analysis. For negative controls an irrelevant isotypic antibody was used as the primary antibody, or no primary antibody at all was used, for both extracted and methanol fixed nuclei.

\section{PCNA}

No DNA denaturation was performed after fixation. Monoclonal anti-PCNA (PC10, Dianova, Hamburg, Germany) was used as primary antibody at a dilution of $1: 10$. Otherwise, processing was performed as described above. 


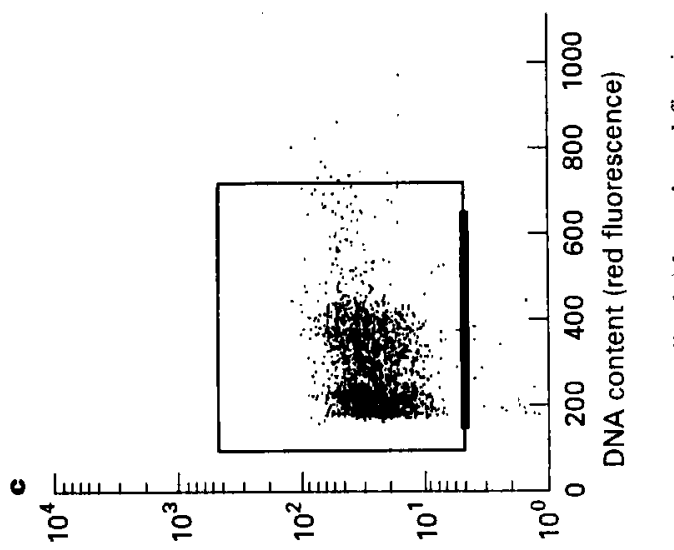

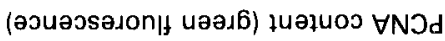

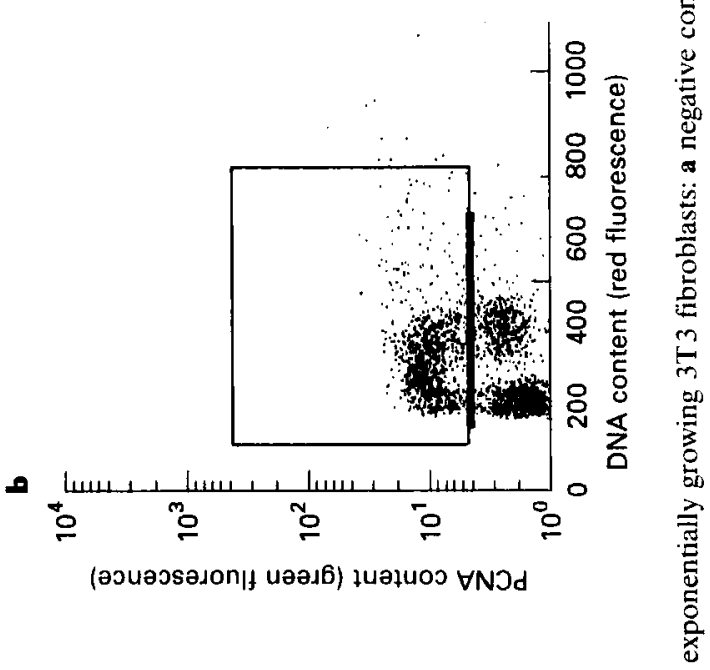

$$
\text { D }
$$

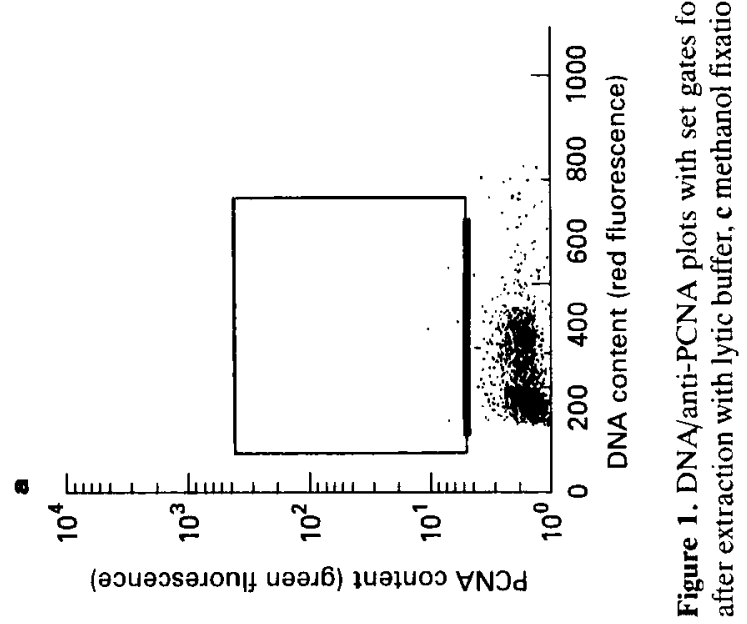


a

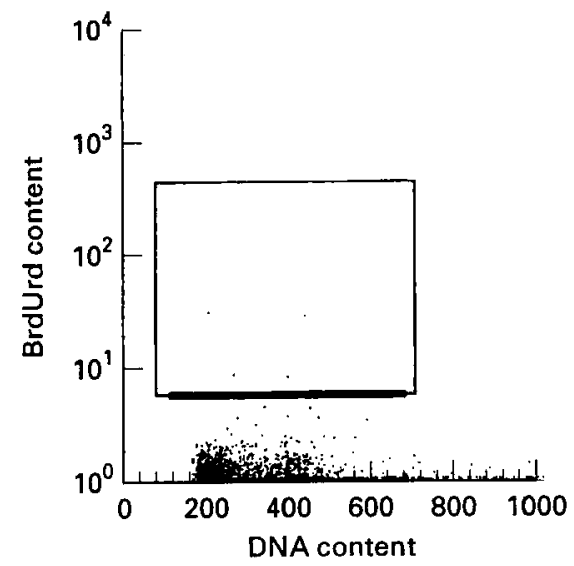

b

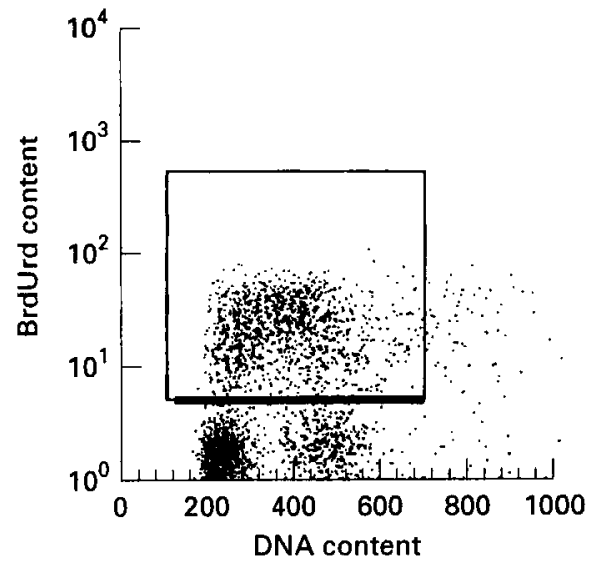

Figure 2. DNA/anti-BrdUrd plots with set gates for exponentially growing 3 T 3 fibroblasts: a negative controls (irrelevant primary antibody), h ethanol fixation.

\section{Flow cytometry}

Analysis was performed with a FACScan flow cytometer (Becton Dickinson). Amplification had to be set differently for BrdUrd and PCNA-detection because of the influence of DNA denaturation but was identical for the detection of total and tightly bound PCNA. Negative controls for both extracted and non-extracted cells were used to determine instrument settings for comparable measurements. At least 10000 events were acquired for each data point. No live gating was performed since few doublets were measured. Remaining doublets were excluded by individual window settings for each measurement. Lower window levels for positive cells were set as shown in Figure 1 so that a maximum of $2 \%$ false positive cells were accepted for negative controls. Experiments were repeated. The results are plotted as the mean of at least two experiments. The difference between actual values and the mean was always less than $15 \%$.

\section{RESULTS}

\section{Fixation and extraction}

Figure 1 shows biparametric plots of DNA content $v$. anti-PCNA-FITC fluorescence in negative controls (non-extracted, methanol fixed), detergent extracted and non-extracted exponentially growing 3T 3 cells after fixation with methanol. Staining after extraction gave good S phase specificity and the cut-off between positive and negative cells could be easily placed. Figure 2 shows negative controls and anti-BrdUrd-staining for the same cells after ethanol fixation, which was superior to methanol fixation in this respect (not shown).

\section{$3 T 3$ fibroblasts}

The index for tightly bound PCNA after detergent extraction showed excellent correlation with BrdUrd-LI under all conditions examined for 3T3 mouse fibroblasts. After serum induction, tightly bound PCNA and BrdUrd-LI increased at the same time and this was paralleled by an increase of cells with an S phase DNA-content in the DNA profile (Figure 3). For both exponential and plateau-phase the number of cells expressing tightly bound PCNA paralleled the fraction of BrdUrd-positive cells after serum withdrawal and after serum induction within less 

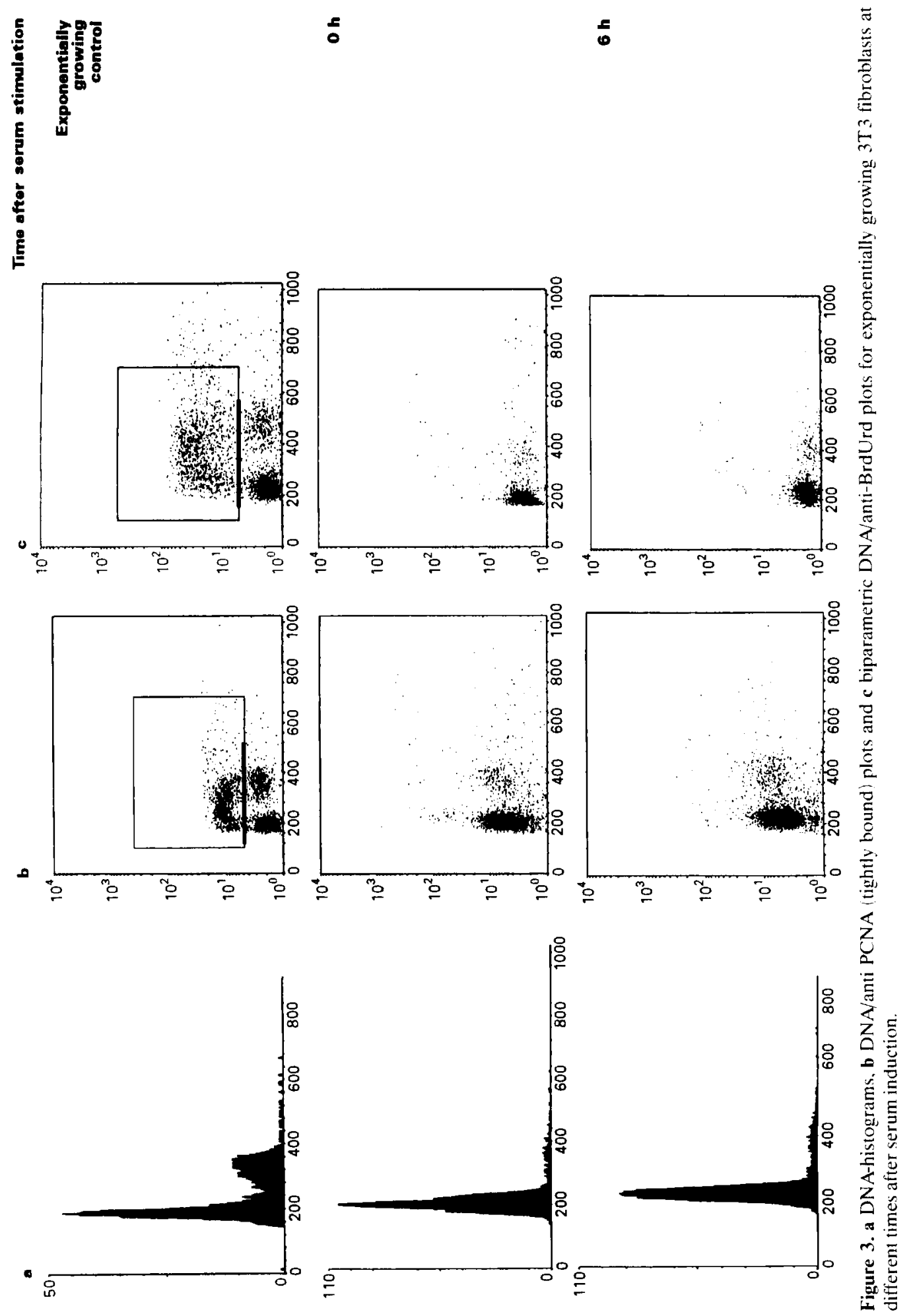


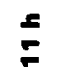

เ

ำ
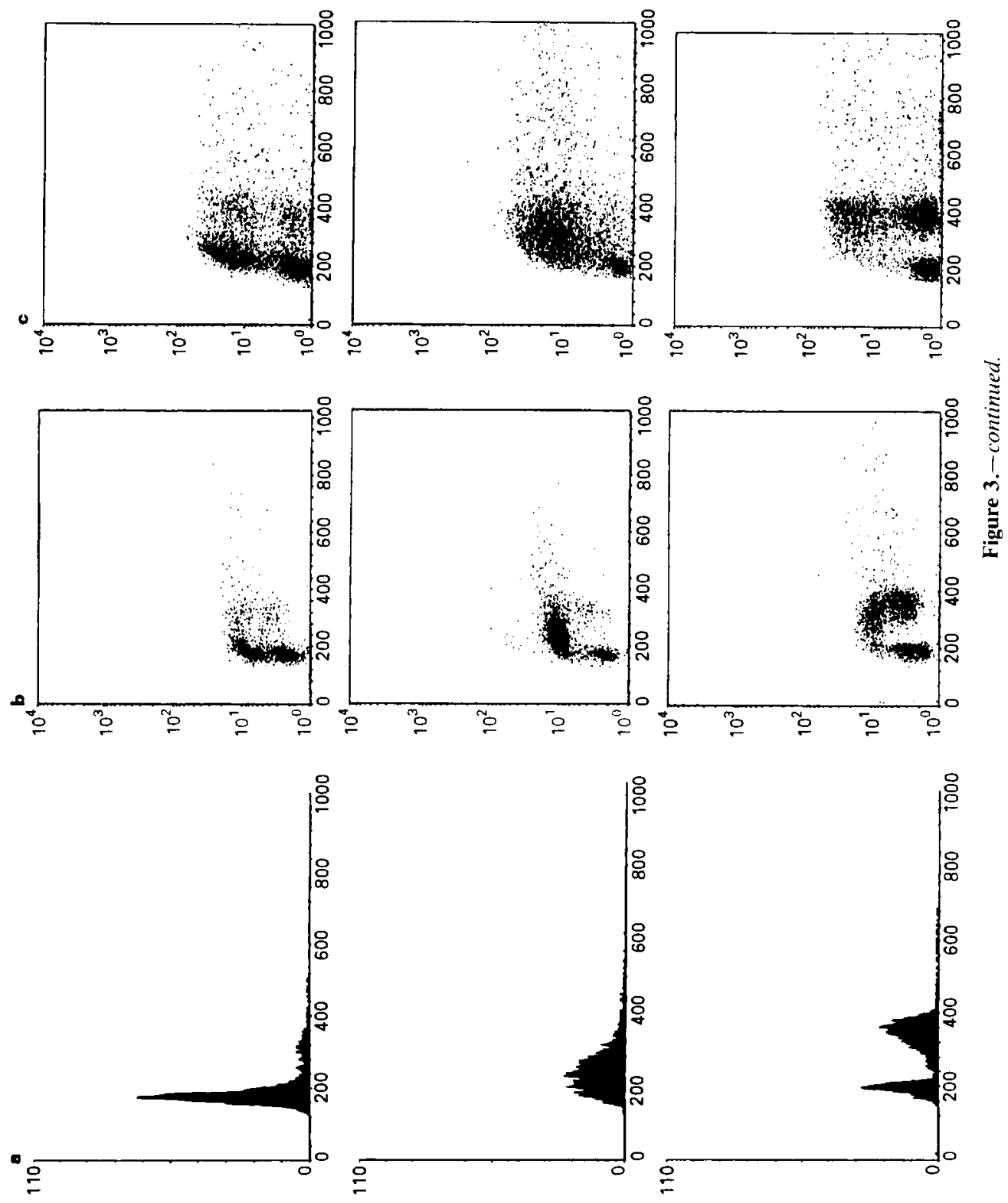

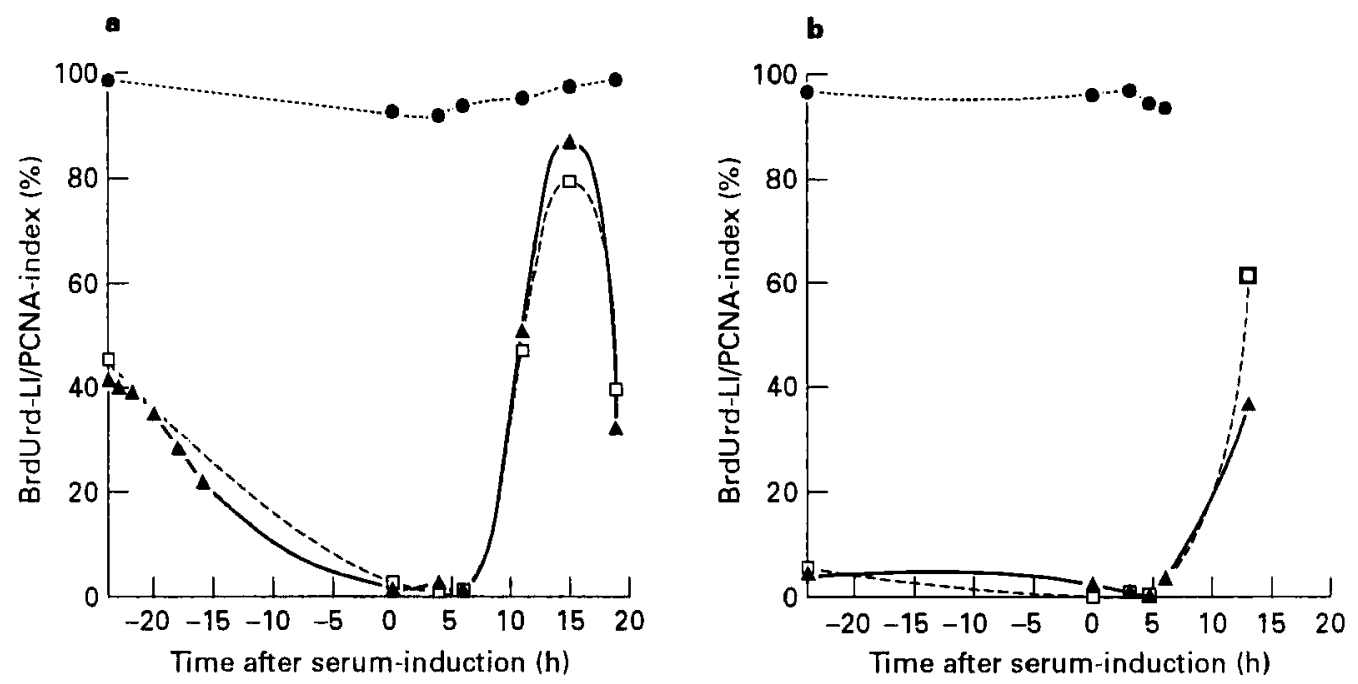

Figure 4. a BrdUrd-LI, total PCNA-index and tightly bound PCNA-index (all as \%) after serum withdrawal $(-24 \mathrm{~h})$ and serum induction $(0 \mathrm{~h})$ for exponentially growing $3 \mathrm{~T} 3$ fibroblasts. b BrdUrd-L.I, total PCNAindex and tightly bound PCNA-index after serum withdrawal $(-24 \mathrm{~h})$ and serum induction (0h) for 3T 3 fibroblasts in plateau-phase ( 6 days of confluency). $\Delta$, tightly bound PCNA index; $\square$, BrdUrd-LI; $\bullet$, total PCNA index.
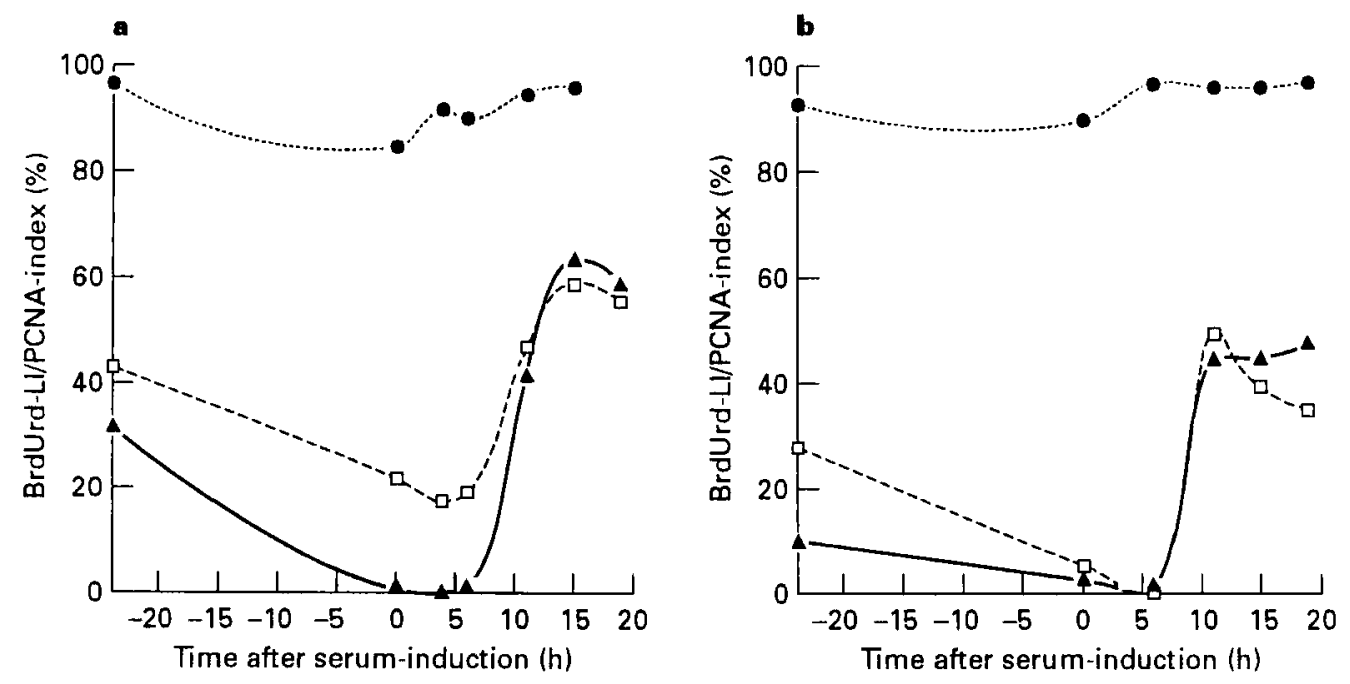

Figure 5. a BrdUrd-LI, total PCNA-index and tightly bound PCNA-index after serum withdrawal $(-24 \mathrm{~h})$ and serum induction $(0 \mathrm{~h})$ for exponentially growing human Caski cells. b BrdUrd-LI, total PCNA-index and tightly bound PCNA-index after serum withdrawal $(-24 \mathrm{~h})$ and serum induction $(0 \mathrm{~h})$ for human Caski cells in plateau-phase ( 6 days of confluency). $\boldsymbol{\Delta}$, tightly bound PCNA index; $\square$, BrdUrd-LI; $\bullet$, total PCNA index. 

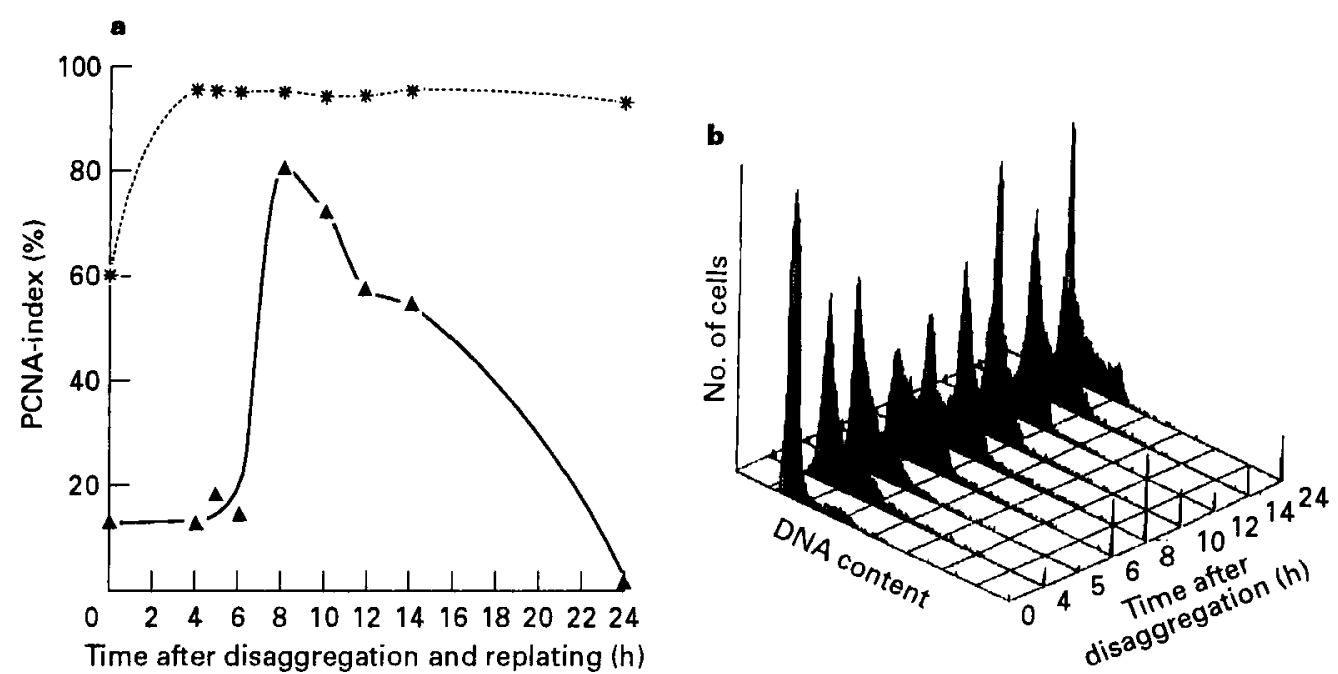

Figure 6. a PCNA-index at different times after disaggregation of V79 spheroids and replating as monolayers. $\boldsymbol{A}$, tightly bound PCNA index; * total PCNA index. b DNA profiles at different times after disaggregation of V79-spheroids and replating as monolayers.

than $3 \%$ variation, except for the data at $10 \mathrm{~h}$ (Figure $4 \mathrm{~b}$ ), 15 and $19 \mathrm{~h}$ (Figure $4 \mathrm{a}$ ) where a variation of 8 to $23 \%$ was seen (Figure $4 a, b$ ). Total PCNA was close to $100 \%$ positive cells in all experiments (Figure $4 a, b$ ).

\section{Caski cells}

For Caski cells there was also a correlation between BrdUrd-LI and tightly bound PCNA index. While, however, after serum induction the fractions of positive cells were similar (Figure 5a,b), after serum withdrawal of exponentially growing cells up to $20 \%$ BrdUrd-positive cells could be detected while almost no cells were positive for tightly bound PCNA (Figure 5a). Similarly, almost $30 \%$ BrdUrd-positive cells were observed with only $10 \%$ positivity for tightly bound PCNA for confluent cells prior to serum withdrawal. Yet, mean anti-BrdUrd fluorescence decreased parallel to the decrease in tightly bound PCNA (not shown).

\section{V79 spheroids}

The appearance of total PCNA and tightly bound PCNA paralleled the appearance of $S$ phase cells in the DNA histogram after 4-6 h (Figure 6). Tightly bound PCNA declined as the S phase fraction declined when the partially synchronized cells progressed through the cell cycle. This was confirmed by determination of the maximum mitotic index (not shown). Total PCNA remained elevated.

\section{DISCUSSION}

In immunohistochemistry, using different anti-PCNA antibodies and different fixation protocols, either granular or diffuse nuclear staining was reported, resembling either the $S$ phase fraction or values similar to the Ki-67-index (Bravo \& McDonald-Bravo 1984, Bravo \& McDonald-Bravo 1987, Landberg \& Roos 1991, Shrestha et al. 1992, Sasaki et al. 1993). Its prognostic value has been discussed with some controversy (Sullivan \& Mortimer 1993). Among others, one reason 
may be that the above mentioned antibodies detect different epitopes which differ in stability to fixation (Roos et al. 1993). Studying PCNA in vitro under different proliferative conditions may help to interpret this in vivo data.

Using flow cytometry instead of immunohistochemistry has the advantage of overcoming topical heterogeneity of PCNA-expression in biopsies. However, this may also be a disadvantage since information about the spatial distribution of proliferation is lost. Moreover, identification of PCNA-positive $v$. negative cells is more reliable with flow cytometry than with immunohistochemistry, since placement of the cut-off between negative and positive cells is easier than in histochemistry because antibody dilution influences the intensity of PCNA staining (McCormick et al. 1993).

Since the BrdUrd assay is currently the standard method for detection of S phase cells in cell cultures or tumours, any possible alternative method has to be compared to this standard. The resulting good $\mathrm{S}$ phase specificity and DNA profiles in our study with the antibody of the clone PC10 confirm the results of Landberg and Wilson(Landberg \& Roos 1991, Wilson et al. 1992).

As the functional association of PCNA with DNA-replication suggests, in our studies the tightly bound PCNA-index showed excellent correlation with BrdUrd-LI for 3T3 mouse fibroblasts, except for the data points late after serum induction. However, these data points are in the steep parts of the curves and, thus, little variation in timing between induction and measurement may cause large variations in PCNA-expression.

For human Caski cells there was also good correlation, although the results were not identical, since after serum starvation in exponentially growing cells up to $20 \%$ BrdUrd-positive cells could be detected, while almost no cells were positive for tightly-bound PCNA. For confluent cells prior to serum withdrawal there was also up to $25 \%$ BrdUrd-positive cells with only $10 \%$ positive cells for tightly bound PCNA. However, mean anti-BrdUrd-fluorescence decreased, indicating a reduced rate of DNA-synthesis.

The observed phenomenon suggests some remaining DNA-synthesis that is either independent of PCNA-expression under in vitro conditions of restrained growth (serum starvation and confluency) or which only requires small levels of PCNA whose fluorescence level is below our detection threshold (cut-off). This discrepancy is somewhat contradictory to the theory that malignant and benign cells that are adjacent to tumours show enhanced PCNA protein expression even when not cycling because of paracrine deregulation of protein transcription (Hall et al. 1990). However, studies which have suggested this mechanism have lacked a marker such as BrdUrd as a standard. Other authors did not find such a phenomenon (Bleiberg, Morret \& Galand 1993). More recently, true growth stimulation (possibly paracrine) of cells was considered more likely (Scott et al. 1991). Yet, the possibility of deregulation should not totally be dismissed since there is evidence (Ottavio et al. 1990) of increased PCNA-expression at the mRNA-level in fully quiescent cells after destruction of intron 4 in the PCNA-gene. Another possible, but unlikely explanation, is that tightly bound PCNA might be more easily extractable in serum depleted Caski cells than in 3T3-cells. Increased PCNA protein expression without DNA-synthesis, on the other hand, was also observed (Sasaki et al. 1993) in vitro, indicating that there is not always an exact coordination between cell proliferation and PCNA-expression.

The results with spheroids as a model for a 3-D-cell system with oxygen, proliferation and nutrient-gradients with most cells supposed to be in the $G_{0}$ phase are in agreement with the results obtained from monolayer cells. The increase and decrease of tightly bound PCNA paralleled the appearance and disappearance of cells with $\mathrm{S}$ phase DNA-content after disaggregation.

The results of our flow cytometric studies in all three cell lines confirm previous data obtained by immunoblotting techniques concerning the expression of PCNA after serum induction (Bravo \& McDonald-Bravo 1987). Being close to $100 \%$ for all the performed experiments, even after 
$24 \mathrm{~h}$ serum withdrawal, the total PCNA index does not reflect changes in proliferative status in these rapidly cycling cells, mainly due to the long half life of PCNA. However, the proliferative status of more slowly proliferating human tumours does not change as quickly as in cultured cells. Thus, the total PCNA content in human tumours might be correlated to tightly bound PCNA. The feasability of flow cytometric PCNA detection in human tumours has been reported (Danova et al. 1988, Teague \& El-Naggar 1994, Inada et al. 1993). Correlation of total PCNA-content to tightly bound PCNA is suggested by the good rank correlation between the PCNA-index without extraction and the BrdUrd-LI in three rat tumour sublines and the variations in non-extracted PCNA-index between 5 and 70\% in human head and neck tumours (Lohr et al. 1993, Wenz et al. 1994). However, a reason for this might be that, after disaggregation, some soluble PCNA is extracted and, even without detergent lysis, preferably tightly bound PCNA is measured in solid tumours. However, both theories provide a rationale for using PCNA as an operational marker of proliferation in human tumours.

\section{ACKNOWLEDGEMENTS}

The authors thank Mrs Trinh and Mrs Haner for their expert maintenance of cell cultures and spheroids.

\section{REFERENCES}

Begg, aC, Hofland I, van Glabekke M, Bartelink H, Horiot JC. (1992) Predictive value of potential doubling time for radiotherapy of head and neck tumor patients: Results from the EORTC cooperative trial 22851. Semin. Radiat. Oncol. $2,22$.

Begg AC, McNaliy NJ, Shrieve DC, Karcher H. (1985) A method to measure the duration of DNAsynthesis and the potential doubling time from a single sample. Cytometry 6, 620 .

Bleiberg H, Morret M, Galand P. (1993) Correlation between ${ }^{3} \mathrm{H}-\mathrm{Thymidine}$ and Proliferating Cell Nuclear Antigen (PCNA)/Cyclin indices in archival, formaldehyde-fixed human colorectal tissues. Eur. J. Cancer, 29A, 400.

Bravo R, MacDonald-Bravo H. (1984) Induction of the nuclear protein "cyclin" in quiescent mouse 3 T3 cells stimulated by serum and growth factors. Correlation with DNA-synthesis. EMBO Journal 3, 3177.

Bravo R, MacDonald-Bravo H. (1987) Existence of two populations of cyclin/proliferating cell nuclear antigen during the cell cycle: Association with DNA-replication sites. J. Cell. Biol. 105, 1549.

Brown DC, GatTer KC. (1990) Monoclonal antibody Ki-67: its use in histopathology. Histopathology 17, 489.

Danova M, Riccardi A, Giordano M et al. (1988) Cell cycle-related proteins: a flow cytofluorometric study in human tumors. Biol. Cell. 64, 23.

Dolbeare F, Gratzner H, Pallavicini MG, Gray JW. (1983) Flow cytometric measurement of total DNA content and incorporated bromodeoxyuridine. Proc. Natl. Acad. Sci. USA 80, 5573.

Duchrow M, Gerdes J, Schlüter C. (1994) The proliferation-associated Ki-67 protein: definition in molecular terms. Cell Prolif. 27, 235.

Galand P, Degraef C. (1989) Cyclin/PCNA immunostaining as an alternative to tritiated thymidine pulse labelling for marking $\mathrm{S}$ phase cells in paraffin sections from animal and human tissues. Cell Tissue Kinet. 22, 383.

Hall PA, Levison DA, Woods AL et al. (1990) Proliferating cell nuclear antigen (PCNA) immunolocalization in paraffin sections: An index of cell proliferation with evidence of deregulated expression in some neoplasms. J. Pathol. 162, 285.

Humbert C, Santisteban MS, Usson Y, Robert-Nicoud M. (1992) Intranuclear co-location of newly replicated DNA and PCNA by simultaneous immunofluorescent labelling and confocal microscopy in MCF-7 cells. J. Cell. Sci. 103, 97.

Inada T, Imura J, Ichikawa A, Ogata Y, Shimamura K. (1993) Proliferative activity of gastric cancer assessed by immunostaining for proliferating cell nuclear antigen. J. Surg. Oncol. 54, 146. 
Jakulski D, DeRiel. JK, Mercer WE, Calabretta B, Baserga R. (1988) Inhibition of cellular proliferation by antisense oligodeoxynucleotides to PCNA/Cyclin. Science 10, 1544.

LANDberg G, Roos G. (1991) Antibodies to proliferating cell nuclear antigen as S-phase probes in tlow cytometric cell cycle analysis. Cancer Res. $\mathbf{5 1}, 4570$.

Lohr F, Wenz F, Flentje M. Peschke P, Hahn EW. (1993) Measurement of the proliferative activity of three different sublines of the Dunning rat prostate tumor R3327. Strahlenther. Onkol. 7, 438.

McCormick D, Yu C, Hosis C, HaL PA. (1993) The relevance of antibody concentration to the immunohistological quantification of cell proliferation-associated antigens. Histopathology 22, 543.

Mathews MB, Bernstein RM, Franza BR, Garrels JI. (1984) Identity of the proliferating cell nuclear antigen and cyclin. Nature 309, 374.

Miyach! K, Fritzler MJ, TAN EM. (1978) Autoantibody to a nuclear antigen in proliferating cells. J. Immunol. 121, 2228.

Ottavio L, Chang CD, Rizzo MG, Ttravali S, Casadevall C, Baserga R. (1990) Importance of introns in the growth regulation of mRNA levels of the Proliferating Cell Nuclear Antigen gene. Mol. Cell. Biol. 10, 303 .

Prelich G, Tan CK, Kostura M el al. (1987) Functional identity of proliferating cell nuclear antigen and a DNA polymerase- $\delta$ auxiliary protein. Nature 326, 517 .

Roos G, Landberg G, Huff JP, Houghten R, Takasaki Y, Tan EM. (1993) Analysis of the epitope of proliferating cell nuclear antigen recognized by monoclonal antibodies. Lab. Invest. 68, 204.

SASAKI K, Kurose A, IshidA Y. (1993) Flow cytometric analysis of the expression of PCNA during the cell cycle in HeLa cells and effects on the inhibition of DNA synthesis on it. Cytometry 14,876.

Scott RJ, Hall PA, Haldane JS et al. (1991) A comparison of immunohistochemical markers of cell proliferation with experimentally determined growth fraction. J. Pathol. 165, 173.

Schlüter C, Duchrow M, Wohlenberg C et al. (1993) The proliferation-associated antigen of antibody Ki67: A very large, ubiquitous nuclear protein with numerous repeated elements, representing a new kind of cell cycle-maintaining proteins. J. Cell Biol. 123, 513.

Sunj MKK, Kenny MK, Wood RD. (1992) Proliferating cell nuclear antigen is required for DNA excision repair. Cell $69,367$.

Shrestiha P, Yamada K, Wada T et al. (1992) Proliferating cell nuclear antigen in breast lesions: correlation of c-erbB-2 oncoprotein and $\mathrm{EGF}$ receptor and its clinicopathological significance in breast cancer. Virchows Archiv A. Pathol. Anat. 421, 193.

Stivala LA, Prosperi E, Rossi R, BIAnch L. (1993) Involvement of proliferating cell nuclear antigen in DNA repair after damage induced by genotoxic agents in human fibroblasts. Carcinogenesis 14, 2569.

Sullivan RP, Mortimer G. (1993) Value of PCNA and Ki67 staining in breast cancer. J. Clin. P'athol. 46, 188.

Teague K, El-Naggar A. (1994) Comparative flow cytometric analysis of Proliferating Cell Nuclear Antigen (PCNA) antibodies in human solid neoplasms. Cytometry $15,21$.

Toschi L, Bravo R. (1988) Changes of cyclin/proliferating cell nuclear antigen distribution during repair synthesis. J. Cell. Biol. 107, 1623.

Vriz S, Lemaitre JM, Leibovici M, Thierry N, Mechali M. (1992) Comparative analysis of the intracellular localization of c-myc, $\mathrm{c}$-fos, and replicative proteins during cell cycle progression. Mol. Cell. Biol. 12, 3548 .

WENZ F, LOHR F, FLENTJE M. (1994) Flow cytometric measurement of proliferating cell nuclear antigen (PCNA) in solid tumors. Strahlenther. Onkol. 170, 235.

Wilson GD, Camplejohn RS, Martindale CA, Brock A, Lane DP, Barnes DM. (1992) Flow cytometric characterization of proliferating cell nuclear antigen using the monoclonal antibody PC10. Eur. J. Cancer 28A, 2010.

Yu CCW, Woods AL, LEvison DA. (1992) The assessment of cellular proliferation by immunohistochemistry: a review of currently available methods and their applications. Histochem. J. 24, 121. 